\title{
MITIGASI KARAKTER MUKA AIR BANJIR DARI MORFOMETRI DAS WAI LONING - NEGERI LAHA, BERBASIS GEOGRAPHIC INFORMATION SYSTEM (GIS)
}

\author{
Steanly R.R.Pattiselanno ${ }^{1)}$, Agus K.Soetrisno ${ }^{2)}$, \\ ${ }^{1,2)}$ Jurusan Teknik Sipil, Politeknik Negeri Ambon \\ ${ }^{1)}$ steanly.r.r.pattiselanno@gmail.com, ${ }^{2)}$ agus.k.soetrisno@gmail.com
}

\begin{abstract}
The streams character of rivers in Ambon Island, has only one main river flow from upstream to downstream or one main river that will be divided into several streams downstream. This is difference from the character of the Wai Loning River that divides Laha Village, which receives the flow from the other two main rivers, that is Wai Sakula and Wai Tengah, which causes the potential of flood discharge to multiply more, especially in the rainy season.Based on that, a study research of the potential flood and waters characteristic of the watershed that formed by the Wai Sakula - Wai Tengah - Wai Loning basin, is required. The survey of watershed, are needed to collect the parameters of watershed morphometric. Technical data required for Wai Loning watersheds, include river morphometry as is: watershed area, length of watershed, width of river basin, slope of river gradient data, order and level of river branching, river density, and watershed shape.Based on the results of identification data that $W_{R_{b}}=12,33$ dan $R_{c}=0,25$, Wai Loning Watershed that lies between $3^{\circ} 40^{\prime} 6,51^{\prime \prime}-3^{\circ} 43^{\prime} 19,50^{\prime \prime}$ 'LS dan $128^{\circ} 1{ }^{\prime} 17,20^{\prime \prime}-128^{\circ} 5^{\prime} 26,98^{\prime \prime}$ BT, with the sum of area of $35.674 .050,00 \mathrm{~m}^{2}\left(35,67 \mathrm{~km}^{2}\right)$ or $3.567,405 \mathrm{Ha}$, with the perimeter of $41.990,00 \mathrm{~m}(41,99 \mathrm{~km})$,evidentlyas river basin that has rapidly rising and receded flood character of waters and rapidly delivered the high peak, as well as the decline.
\end{abstract}

\begin{abstract}
ABSTRAK
Karakter sungai di Pulau Ambon memiliki ciri hanya satu aliran sungai utama dari hulu ke hilir ataupun satu aliran sungai utama yang akan terbagi menjadi beberapa anak sungai di arah hilir. Ini berbeda dengan karakter sungai Wai Loning yang membelah Negeri Laha yang menerima aliran dari dua sungai utama lainnya yaitu Wai Sakula dan Wai Tengah, yang menyebabkan potensi debit banjirnya menjadi berkali lipat lebih banyak terutama di musim hujan. Berdasarkan hal tersebut, maka diperlukan suatu kajian studi penelitian tentang potensi karakter muka air banjir aliran sungai pada DAS yang dibentuk oleh kesatuan aliran Wai Sakula - Wai Tengah - Wai Loning, yang pastinya membutuhkan survey kawasan DAS demi mengumpulkan parameter morfometri DAS. Data teknis yang diperlukan untuk DAS Wai Loning berupa morfometri sungai yang meliputi: luas DAS, panjang DAS, lebar DAS, kemiringan data gradien sungai, orde dan tingkat percabangan sungai, kerapatan sungai, dan bentuk DAS. Berdasarkan hasil identifikasi data $W_{R_{b}}=12,33$ dan $R_{c}=0,25$, maka DAS Wai Loning yang terbentang antara $3^{\circ} 40^{\prime} 6,51^{\prime \prime}-3^{\circ} 43^{\prime} 19,50^{\prime \prime} \mathrm{LS}$ dan $128^{\circ} 1{ }^{\prime} 17,20^{\prime \prime}-128^{\circ} 5^{\prime} 26,98^{\prime \prime}$ BT dengan luas $35.674 .050,00 \mathrm{~m}^{2}\left(35,67 \mathrm{~km}^{2}\right)$ atau 3.567,405 Ha, dan keliling 41.990,00 m (41,99 km)termasuk karakter DAS dimana sungainya mengalami kenaikan dan penurunan muka air banjir yang berlangsung dengan cepat sertakarakter debit puncak yang datang dengan cepat, begitu juga penurunannya.
\end{abstract}

Kata kunci: morfometri; mitigasi; banjir; Wai Loning; Wai Tengah; Wai Sakula; Negeri Laha

\section{PENDAHULUAN}

Politeknik Negeri Ambon melalui Pusat Penelitian dan Pengabdian kepada Masyarakat setiap tahun memilih satu kawasan/desa tertentu untuk dijadikan kawasan/desa binaan, antara lain Desa Liang pada tahun 2016. Pada tahun 2017 ini, Negeri Laha terpilih untuk dijadikan desa binaan Politeknik Negeri Ambon sebagai kawasan bagi studi penelitian maupun pengabdian bagi masyarakat. Negeri Laha merupakan desa dengan posisi yang cukup strategis, karena letaknya yang menyatu dengan Bandara Internasional Patimura Ambon. Akibatnya, Negeri Laha pasti akan selalu menerima dampak dari pembenahan infrastruktur pada kawasan bandara, salah satunya adalah pembuangan/outlet dari sistem drainase kawasan bandara yang menerima aliran dari 3 sungai yaitu Wai Sakula dan Wai Tengah yang bermuara pada sungai ketiga yaitu Wai Loning yang melintasi tengah bandara dan bermuara di perkampungan Negeri Laha (Sumber: Peta RBI Pulau Ambon NLP 2612-23 produksi Badan Informasi Geospasial, 2008).

Secara umum, karakter sungai di Pulau Ambon memiliki ciri hanya satu aliran sungai utama dari hulu ke hilir ataupun satu aliran sungai utama yang akan terbagi menjadi beberapa anak sungai di arah hilir. Ini berbeda dengan karakter sungai Wai Loning yang membelah Negeri Laha yang menerima aliran dari dua sungai utama lainnya yaitu Wai Sakula dan Wai Tengah, yang menyebabkan potensi debitnya menjadi berkali lipat lebih banyak terutama di musim hujan. 


\section{JURNAL SIMETRIK VOL 7, NO. 2, DESEMBER 2017}

Dari pertimbangan faktor-faktor tersebut, diperlukan suatu studi penelitian tentang potensi karakter muka air banjir aliran sungai pada DAS yang dibentuk oleh kesatuan aliran Wai Sakula - Wai Tengah - Wai Loning. Penelitian karakter muka air banjir aliran sungai akan berhasil jika dikerjakan dengan dukungan data teknis sebuah DAS yang baik, seperti data debit aliran sungai, curah hujan di kawasan DAS, dan cakupan area DAS itu sendiri yang didalamnya berisi data topografi, jaringan aliran sungai dan luas kawasan DAS dan sub-sub DAS di dalam area DAS.

Pengumpulan data suatu DAS tidaklah mudah dan memerlukan biaya yang besar jika dilakukan secara konvensional. Proses dan waktu yang dibutuhkan pun relatif cukup panjang. Jika pengumpulan data DAS dilakukan berbasis Sistem Informasi Geografis, maka biaya dan waktu yang dialokasiskan bisa lebih diefisiensi dengan mendapatkan hasil yang lengkap berupa ekstraksi morfometri DAS yang berisi parameter luas DAS, panjang DAS, lebar DAS, kemiringan data gradien sungai, orde dan tingkat percabangan sungai, kerapatan sungai, dan bentuk DAS. Mencermati hal tersebut, maka perlu dilakukan suatu kajian penelitian dengan judul:

"Mitigasi karakter muka air banjir dari morfometri DAS Wai Loning - Negeri Laha, berbasis Geographic Information System (GIS)"

\section{TINJAUAN PUSTAKA}

\subsection{DAS}

DAS adalah suatu wilayah daratan yang secara topografik dibatasi oleh punggung-punggung gunung yang menampung dan meyimpan air hujan (catchment area) untuk kemudian menyalurkannya ke laut melalui sungai utama (Asdak, 2004:4).

\subsection{Morfometri DAS}

Morfometri Daerah Aliran Sungai (DAS) adalah istilah yang digunakan untuk menyatakan keadaan jaringan alur sungai secara kuantitatif. Morfologi DAS meliputi:

1) Luas DAS, meliputi area di dalam garis batas antara punggung permukaan bumi yang dapat memisahkan dan membagi air hujan ke masingmasing DAS

2) Panjang dan lebar DAS. Panjang DAS adalah sama dengan jarak datar dari muara sungai ke arah hulu sepanjang sungai induk, sedangkan lebar DAS adalah pebandingan antara luas DAS dengan panjang sungai induk. Lebar DAS tidak ditentukan dengan pengukuran langsung, tetapi dengan menggunakan rumus sebagai berikut (Seyhan, 1977):

$$
W=\frac{A}{L_{b}}
$$

dimana:

$$
\text { W : Lebar DAS }(\mathrm{km})
$$
A : Luas DAS $\left(\mathrm{km}^{2}\right)$
$\mathrm{L}_{\mathrm{b}} \quad$ : Panjang sungai utama $(\mathrm{km})$

3) Kemiringan atau gradien sungai, merupakan perbandingan beda tinggi antara hulu dengan hilir dan panjang sungai induk. Kemiringan alur sungai rnerupakan parameter dimensional yang menggambarkan besarnya penurunan rerata tiap satuan jarak horizontal tertentu pada saluran sungai utama. Gradien sungai dapat diperkirakan dengan persamaan:

$$
S_{u}=\frac{\left(h_{85}-h_{10}\right)}{0,75 \cdot L_{b}}
$$

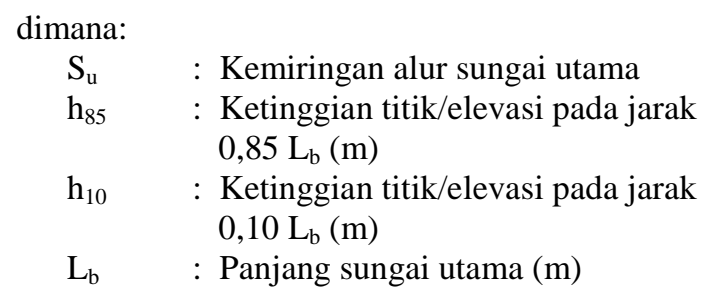

4) Orde dan tingkat percabangan sungai, adalah posisi percabangan alur sungai didalam urutannya terhadap induk sungai pada suatu DAS. Orde sungai dapat ditetapkan dengan metode Horton, Strahler, Shreve, dan Scheidegger. Pada umumnya metode Strahler lebih mudah untuk diterapkan dibandingkan dengan metode yang lainnya. Berdasarkan metode Strahler, alur sungai paling hulu yang tidak mempunyai cabang disebut dengan orde pertama (orde 1), pertemuan antara orde pertama disebut orde kedua (ode 2), demikian seterusnya sampai pada sungai utama ditandai dengan nomor orde yang paling besar (Gambar 1.)

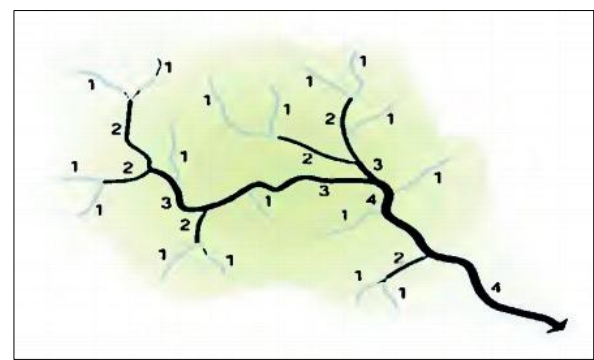

Sumber: T.Hery Purwanto, 2012

\section{Gambar 1. Penentuan alur sungai metode Strahler}

5) Jumlah alur sungai suatu orde dapat ditentukan dari angka indeks percabangan sungai (bifurcation ratio), dengan persamaan berikut:

$$
R_{b}=\frac{N_{u}}{N_{u+1}}
$$

Perhitungan $\mathrm{R}_{\mathrm{b}}$ biasanya dilakukan dalam unit Sub DAS atau sub-sub DAS. Untuk memperoleh 


\section{JURNAL SIMETRIK VOL 7, NO. 2, DESEMBER 2017}

nilai $\mathrm{Rb}$ dari keseluruhan DAS, maka digunakan tingkat percabangan Sungai Rerata Tertimbang (Weighted Mean Bifurcation Ratio / $\mathrm{W}_{\mathrm{Rb}}$ ), yang dihitung dengan menggunakan persamaan berikut:

$$
W_{R_{b}}=\frac{\sum R_{b_{u / u+1}} \cdot\left(N_{u}+N_{u+1}\right)}{N_{u}}
$$

dimana:

$$
\begin{array}{ll}
R_{b} & \text { : Tingkat percabangan sungai } \\
N_{u} & \begin{array}{l}
\text { : Jumlah alur sungai untuk } \\
\text { orde ke-u }
\end{array} \\
N_{u}+1 & \begin{array}{l}
\text { : Jumlah alur sungai untuk } \\
\text { orde ke- }(\mathrm{u}+1)
\end{array}
\end{array}
$$

Hasil persamaan tersebut dapat menyatakan keadaan sebagai berikut:

a) $R_{b}<3$, alur sungai mempunyai kenaikan muka air banjir dengan cepat, sedangkan penurunannya berjalan lambat.

b) $R_{b} 3-5$, alur sungai mempunyai kenaikan dan penurunan muka air banjir tidak terlalu cepat atau tidak terlalu lambat.

c) $R_{b}>5$, alur sungai mempunyai kenaikan muka air banjir dengan cepat, demikian pula penurunannya akan berjalan dengan cepat.

6) Kerapatan sungai, adalah suatu angka indeks yang menunjukkan banyaknya anak sungai di dalam suatu DAS. Kerapatan alur mencerminkan panjang sungai rerata dalam satu satuan luas tertentu, dan dapat dihitung menggunakan rumus sebagai berikut (Seyhan, 1977):

$$
D_{d}=\frac{L_{n}}{A}
$$

\begin{tabular}{|c|c|c|c|}
\hline No & $\begin{array}{c}D_{d} \\
\left(\mathrm{~km} / \mathrm{km}^{2}\right)\end{array}$ & $\begin{array}{c}\text { Kelas } \\
\text { Kerapatan }\end{array}$ & Keterangan \\
\hline 1 & $<0,25$ & Rendah & $\begin{array}{l}\text { Alur sungai melewati } \\
\text { batuan dengan resistensi } \\
\text { keras, maka angkutan } \\
\text { sedimen yang terangkut } \\
\text { aliran sungai lebih kecil } \\
\text { jika dibandingkan pada } \\
\text { alur sungai yang melewati } \\
\text { batuan dengan resistensi } \\
\text { yang lebih lunak, apabila } \\
\text { kondisi lain yang } \\
\text { mempengaruhinya sama. }\end{array}$ \\
\hline
\end{tabular}

\begin{tabular}{|c|c|c|c|}
\hline No & $\begin{array}{c}D_{d} \\
\left(\mathrm{~km} / \mathrm{km}^{2}\right)\end{array}$ & $\begin{array}{c}\text { Kelas } \\
\text { Kerapatan }\end{array}$ & Keterangan \\
\hline 2 & $0,25-10$ & Sedang & $\begin{array}{l}\text { Alur sungai melewati } \\
\text { batuan dengan } \\
\text { resistensi yang lebih } \\
\text { lunak sehingga } \\
\text { angkutan sedimen } \\
\text { yang terangkut akan } \\
\text { lebih besar. }\end{array}$ \\
\hline 3 & $10-25$ & Tinggi & $\begin{array}{l}\text { Alur sungai melewati } \\
\text { batuan dengan } \\
\text { resistensi yang lunak } \\
\text { sehingga angkutan } \\
\text { sedimen yang } \\
\text { terangkut aliran akan } \\
\text { lebih besar. }\end{array}$ \\
\hline 4 & $>25$ & $\begin{array}{c}\text { Sangat } \\
\text { Tinggi }\end{array}$ & $\begin{array}{l}\text { Alur sungai melewati } \\
\text { batuan yang kedap air. } \\
\text { Keadaan ini } \\
\text { menunjukan bahwa air } \\
\text { hujan yang menjadi } \\
\text { aliran akan lebih besar } \\
\text { jika dibandingkan } \\
\text { suatu daerah dengan } \\
D_{d} \text { rendah melewati } \\
\text { batuan yang } \\
\text { permeabilitas besar. }\end{array}$ \\
\hline
\end{tabular}

dimana:

$$
\begin{array}{ll}
D_{d} & : \text { Kerapatan alur }\left(\mathrm{km} / \mathrm{km}^{2}\right) \\
L_{n} & : \text { Total panjang alur }(\mathrm{km}) \\
A & : \text { Luas DAS }\left(\mathrm{km}^{2}\right)
\end{array}
$$

Berikut tabel deskripsi tentang indeks kerapatan sungai (Tabel. 1)

Tabel 1. Indeks kerapatan sungai

Sumber: Soewarno, 1991

7) Bentuk DAS. Pola sungai menentukan bentuk suatu DAS dan mempunyai arti penting dalam hubungannya dengan aliran sungai, yaitu berpengaruh terhadap kecepatan terpusat aliran. Bentuk DAS sulit untuk dinyatakan dalam bentuk kuantitatif, tetapi dapat didekali dengan nisbah kebulatan (cilcularity ratio) menggunakan rumus sebagai berikut:

$$
R_{c}=\frac{4 \pi \cdot A}{P^{2}}
$$

dimana:

$$
\begin{array}{ll}
R_{c} & : \text { Nisbah kebulatan } \\
A & : \text { Luas DAS }\left(\mathrm{km}^{2}\right) \\
P & : \text { Keliling (perimeter) DAS }(\mathrm{km})
\end{array}
$$

Berikut tabel deskripsi tentang nisbah kebulatan $\left(R_{c}\right)$ DAS (Tabel 2.):

Tabel 2. Bentuk Kebulatan (circularity ratio/ $\boldsymbol{R}_{c}$ )

\begin{tabular}{|c|c|l|}
\hline No & $\boldsymbol{R}_{\boldsymbol{c}}$ & \multicolumn{1}{c|}{ Keterangan } \\
\hline 1 & $>0,5$ & $\begin{array}{l}\text { Bentuk Daerah Aliran Sungai membulat, } \\
\text { debit puncak datangnya lama, begitu juga } \\
\text { penurunannya. }\end{array}$ \\
\hline 2 & $<0,5$ & $\begin{array}{l}\text { Bentuk Daerah Aliran Sungai memanjang, } \\
\text { debit puncak datangnya cepat, begitu juga } \\
\text { penurunannya. }\end{array}$ \\
\hline
\end{tabular}

Sumber: Soewarno, 1991 


\section{JURNAL SIMETRIK VOL 7, NO. 2, DESEMBER 2017}

\section{METODOLOGI}

\subsection{Jenis Penelitian}

Jenis penelitian yang dilaksanakan adalah penelitian deskriptif evaluatif (evaluative decriptional research) yang bertujuan memaparkan masalah terjadinya limpahan air yang besar dan menyebabkan banjir di Negeri Laha yang biasanya berasal dari drainase bandara yang meluap di musim penghujan saat ini, melalui evaluasi parameter morfometri DAS Wai Loning - Negeri Laha.

\subsection{Lokasi Penelitian}

Lokasi penelitian dilakukan di DAS Wai Loning Negeri Laha, Kecamatan Teluk Ambon - Kota Ambon - Provinsi Maluku. Secara geografis, DAS Loning terletak antara $3^{\circ} 40^{\prime} 6,51^{\prime \prime}-3^{\circ} 43^{\prime} 19,50^{\prime}$ " LS dan $128^{\circ} 1^{\prime} 17,20^{\prime \prime}-128^{\circ} 5^{\prime} 26,98^{\prime \prime}$ BT (Gambar 2.):

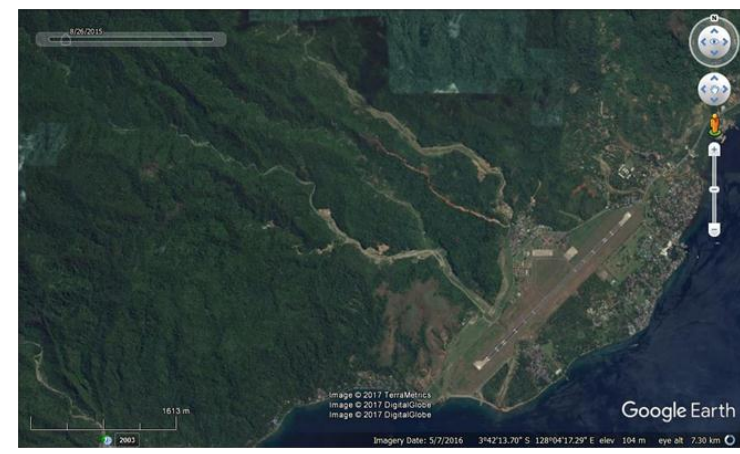

Sumber: Google Earth, 2017

Gambar 2. Lokasi Studi (DAS Wai Loning)

\subsection{Jenis dan Sumber Data}

Jenis data yang dikumpulkan pada dasarnya terdiri dari data ruang (spasial) dan data non ruang yang menggambarkan karakteristik DAS Wai Loning. Data-data yang dibutuhkan adalah:

1) Peta kontur/topografi (sumber: $B I G$, digitasi peta RBI Pulau Ambon, NLP 2612-23, Edisi I Tahun 2008),

2) Peta Daerah Aliran Sungai (sumber: hasil digitasi Peta RBI)

\subsection{Metode Analisa Data}

Analisis data yang perlu dilakukan dalam proses penelitian ini adalah:

1) Membuat peta tematik kontur/topografi Pulau Ambon (*.shp) dari digitasi olahan peta RBI Pulau Ambon, NLP 2612-23 dalam bentuk (*.DWG), Edisi I Tahun 2008 dengan aplikasi ArcGIS MAP 9.3;

2) Membuat peta tematik aliran Sungai Wai Loning (*.shp) dari digitasi olahan peta RBI Pulau Ambon dalam bentuk (*.DWG), NLP 2612-23, Edisi I Tahun 2008 dengan aplikasi ArcGIS MAP 9.3;
3) Pemodelan DAS, dari ekstraksiDEM olahan tematik topografi Pulau Ambon dan aliran sungai Wai Loning yang berisi morfometri sungai pada DAS Wai Loning (meliputi luas DAS, panjang DAS, lebar DAS, kemiringan data gradien sungai, orde dan tingkat percabangan sungai, kerapatan sungai, dan bentuk DAS) dengan toolsAVSWAT 2000 pada ArcView GIS 3.3.

\section{HASIL DAN PEMBAHASAN}

\subsection{Hasil Penelitian}

Letak geografis DAS Wai Loning terbentang pada koordinat $3^{\circ} 38^{\prime} 30,6^{\prime \prime}-3^{\circ} 43^{\prime} 16,3^{\prime \prime} \mathrm{LS}$ dan $128^{\circ} 00^{\prime} 44,7-128^{\circ} 05^{\prime} 19,8^{\prime}$ 'BT dengan luas 35.674.050,00 $\mathrm{m}^{2}\left(35,67 \mathrm{~km}^{2}\right)$ dan keliling DAS Wai Loning adalah 41.990,00 m (41,99 km). DAS Wai Loning juga terbagi atas 31 SubDAS. Berikut data atribut DAS, Sub DAS dan Sungai Wai Loning (Tabel 3. - Tabel 5.)

Tabel 3. Data atribut DAS Wai Loning

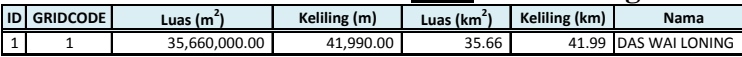

Sumber : Analisa Spasial ArcView GIS 3.3 \& ArcGIS 9.3, 2017

Tabel 4. Data atribut SUB BASIN - DAS Wai Loning

\begin{tabular}{|c|c|c|c|c|c|}
\hline SUBBASIN & AREA (Ha) & Luas $\left(\mathrm{m}^{2}\right)$ & $\begin{array}{c}\text { Keliling } \\
\text { (m) }\end{array}$ & $\begin{array}{l}\text { Luas } \\
\left(\mathrm{km}^{2}\right)\end{array}$ & $\begin{array}{c}\text { Keliling } \\
\text { (km) }\end{array}$ \\
\hline 1 & 125.8550 & $1,258,550$ & 6,260 & 1.26 & 6.26 \\
\hline 2 & 102.6050 & $1,026,050$ & 5,970 & 1.03 & 5.97 \\
\hline 3 & 82.8950 & 828,950 & 5,810 & 0.83 & 5.81 \\
\hline 4 & 57.9125 & 579,125 & 4,230 & 0.58 & 4.23 \\
\hline 5 & 96.0250 & 960,250 & 5,780 & 0.96 & 5.78 \\
\hline 6 & 61.7075 & 617,075 & 5,200 & 0.62 & 5.20 \\
\hline 7 & 109.1675 & $1,091,675$ & 6,430 & 1.09 & 6.43 \\
\hline 8 & 80.3725 & 803,725 & 4,930 & 0.80 & 4.93 \\
\hline 9 & 139.5125 & $1,395,125$ & 7,750 & 1.40 & 7.75 \\
\hline 10 & 75.6525 & 756,525 & 5,750 & 0.76 & 5.75 \\
\hline 11 & 16.5775 & 165,775 & 2,620 & 0.17 & 2.62 \\
\hline 12 & 50.4800 & 504,800 & 4,460 & 0.50 & 4.46 \\
\hline 13 & 204.9550 & $2,049,550$ & 11,410 & 2.05 & 11.41 \\
\hline 14 & 246.4550 & $2,464,550$ & 10,450 & 2.46 & 10.45 \\
\hline 15 & 12.8100 & 128,100 & 2,070 & 0.13 & 2.07 \\
\hline 16 & 91.7350 & 917,350 & 5,890 & 0.92 & 5.89 \\
\hline 17 & 62.7375 & 627,375 & 4,150 & 0.63 & 4.15 \\
\hline 18 & 58.0375 & 580,375 & 4,520 & 0.58 & 4.52 \\
\hline 19 & 60.2275 & 602,275 & 5,160 & 0.60 & 5.16 \\
\hline 20 & 151.8000 & $1,518,000$ & 7,310 & 1.52 & 7.31 \\
\hline 21 & 261.5475 & $2,615,475$ & 12,540 & 2.62 & 12.54 \\
\hline 22 & 221.5750 & $2,215,750$ & 11,550 & 2.22 & 11.55 \\
\hline 23 & 3.6125 & 36,125 & 1,240 & 0.04 & 1.24 \\
\hline 24 & 46.9175 & 469,175 & 4,330 & 0.47 & 4.33 \\
\hline 25 & 183.6350 & $1,836,350$ & 8,950 & 1.84 & 8.95 \\
\hline 26 & 60.7400 & 607,400 & 4,140 & 0.61 & 4.14 \\
\hline 27 & 88.2225 & 882,225 & 5,720 & 0.88 & 5.72 \\
\hline 28 & 51.8425 & 518,425 & 4,110 & 0.52 & 4.11 \\
\hline 29 & 685.3300 & $6,853,300$ & 21,740 & 6.85 & 21.74 \\
\hline 30 & 54.5050 & 545,050 & 3,990 & 0.55 & 3.99 \\
\hline \multirow[t]{2}{*}{31} & 21.9575 & 219,575 & 3,180 & 0.22 & 3.18 \\
\hline & $3,567.4050$ & $35,674,050$ & & 35.67 & \\
\hline
\end{tabular}

Sumber : Analisa Spasial ArcView GIS 3.3 \& ArcGIS $9.3,2017$ 


\section{JURNAL SIMETRIK VOL 7, NO. 2, DESEMBER 2017}

Tabel 5. Data atribut SUNGAI - DAS Wai Loning

\begin{tabular}{|c|r|r|}
\hline SUBBASIN & $\begin{array}{r}\text { Panjang } \\
\text { Sungai } \\
\text { [LEN2] (m) }\end{array}$ & $\begin{array}{c}\text { Panjang } \\
\text { Sungai } \\
\text { (km) }\end{array}$ \\
\hline \hline $\mathbf{1}$ & $\mathbf{8 7 0 . 7 2}$ & 0.87 \\
\hline $\mathbf{2}$ & $\mathbf{6 8 6 . 6 3}$ & 0.69 \\
\hline $\mathbf{3}$ & $\mathbf{9 0 0 . 0 0}$ & 0.90 \\
\hline $\mathbf{4}$ & $\mathbf{6 2 4 . 5 8}$ & 0.62 \\
\hline $\mathbf{5}$ & $\mathbf{6 2 6 . 7 0}$ & 0.63 \\
\hline $\mathbf{6}$ & $\mathbf{3 4 7 . 6 8}$ & 0.35 \\
\hline $\mathbf{7}$ & $\mathbf{9 6 2 . 4 9}$ & 0.96 \\
\hline $\mathbf{8}$ & $\mathbf{1 , 2 7 8 . 4 5}$ & 1.28 \\
\hline $\mathbf{9}$ & $\mathbf{8 7 0 . 6 4}$ & 0.87 \\
\hline $\mathbf{1 0}$ & $\mathbf{1 , 4 4 5 . 7 8}$ & 1.45 \\
\hline $\mathbf{1 1}$ & $\mathbf{4 6 1 . 3 2}$ & 0.46 \\
\hline $\mathbf{1 2}$ & $\mathbf{1 0 2 . 5 0}$ & 0.10 \\
\hline $\mathbf{1 3}$ & $\mathbf{4 1 4 . 2 5}$ & 0.41 \\
\hline $\mathbf{1 4}$ & $\mathbf{8 0 1 . 4 9}$ & 0.80 \\
\hline $\mathbf{1 5}$ & $\mathbf{2 , 6 2 8 . 0 5}$ & 2.63 \\
\hline $\mathbf{1 6}$ & $\mathbf{2 5 1 . 9 1}$ & 0.25 \\
\hline $\mathbf{1 7}$ & $\mathbf{2 , 4 6 3 . 7 8}$ & 2.46 \\
\hline $\mathbf{1 8}$ & $\mathbf{9 7 3 . 7 6}$ & 0.97 \\
\hline $\mathbf{1 9}$ & $\mathbf{7 7 6 . 5 9}$ & 0.78 \\
\hline $\mathbf{2 0}$ & $\mathbf{9 7 0 . 0 1}$ & 0.97 \\
\hline $\mathbf{2 1}$ & $\mathbf{2 5 1 . 2 3}$ & 0.25 \\
\hline $\mathbf{2 2}$ & $\mathbf{4 , 0 2 5 . 2 1}$ & 4.03 \\
\hline $\mathbf{2 3}$ & $\mathbf{2 , 3 0 1 . 8 1}$ & 2.30 \\
\hline $\mathbf{2 4}$ & $\mathbf{3 , 9 0 2 . 6 7}$ & 3.90 \\
\hline $\mathbf{2 5}$ & $\mathbf{1 , 2 6 9 . 8 1}$ & 1.27 \\
\hline $\mathbf{2 6}$ & $\mathbf{2 5 2 . 4 9}$ & 0.25 \\
\hline $\mathbf{2 7}$ & $\mathbf{9 0 . 7 8}$ & 0.09 \\
\hline $\mathbf{2 8}$ & $\mathbf{1 , 1 1 6 . 6 2}$ & 1.12 \\
\hline $\mathbf{2 9}$ & $\mathbf{1 , 1 2 4 . 6 1}$ & 1.12 \\
\hline $\mathbf{3 0}$ & $\mathbf{8 , 5 4 2 . 7 9}$ & 8.54 \\
\hline $\mathbf{3 1}$ & $\mathbf{1 , 1 6 6 . 8 8}$ & 1.17 \\
\hline & & \\
\hline & & \\
\hline & & \\
\hline
\end{tabular}

Sumber : Analisa Spasial ArcView GIS 3.3 \& ArcGIS 9.3, 2017

Berikut peta DAS, Sub BASIN dan Orde Jaringan Sungai Wai Loning Metode Strahler (Gambar 3.- Gambar 5.):

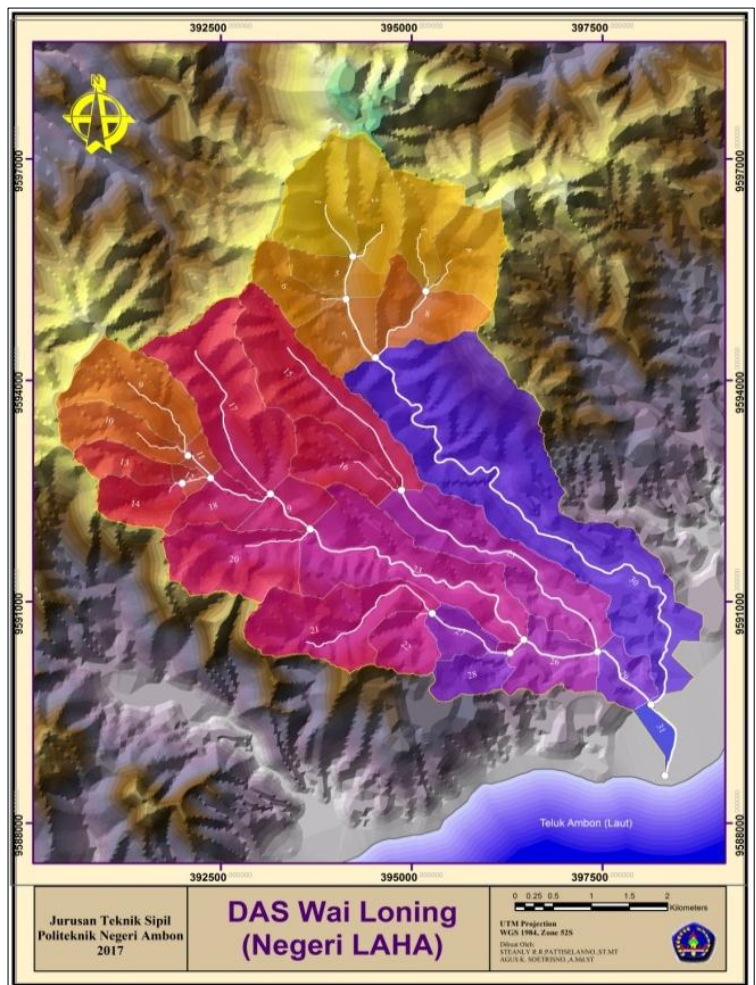

Sumber : Hasil Olahan, 2017

Gambar 3. Peta DAS Wai Loning

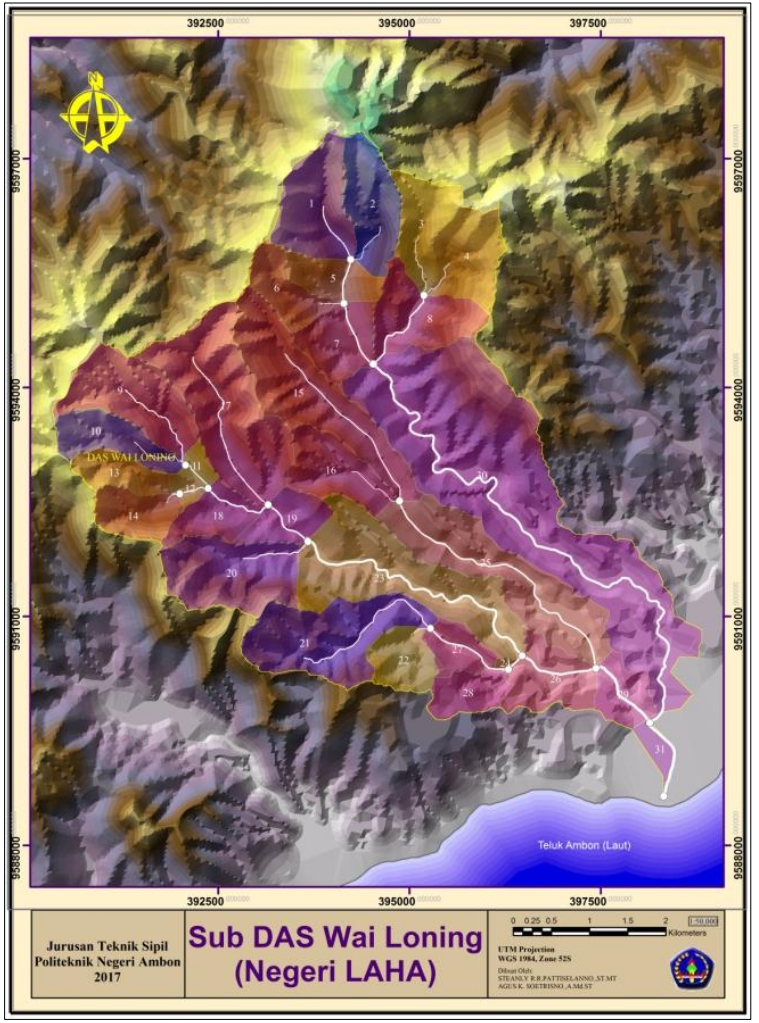

Sumber : Hasil Olahan, 2017

Gambar 4. Peta Sub-BASIN Wai Loning

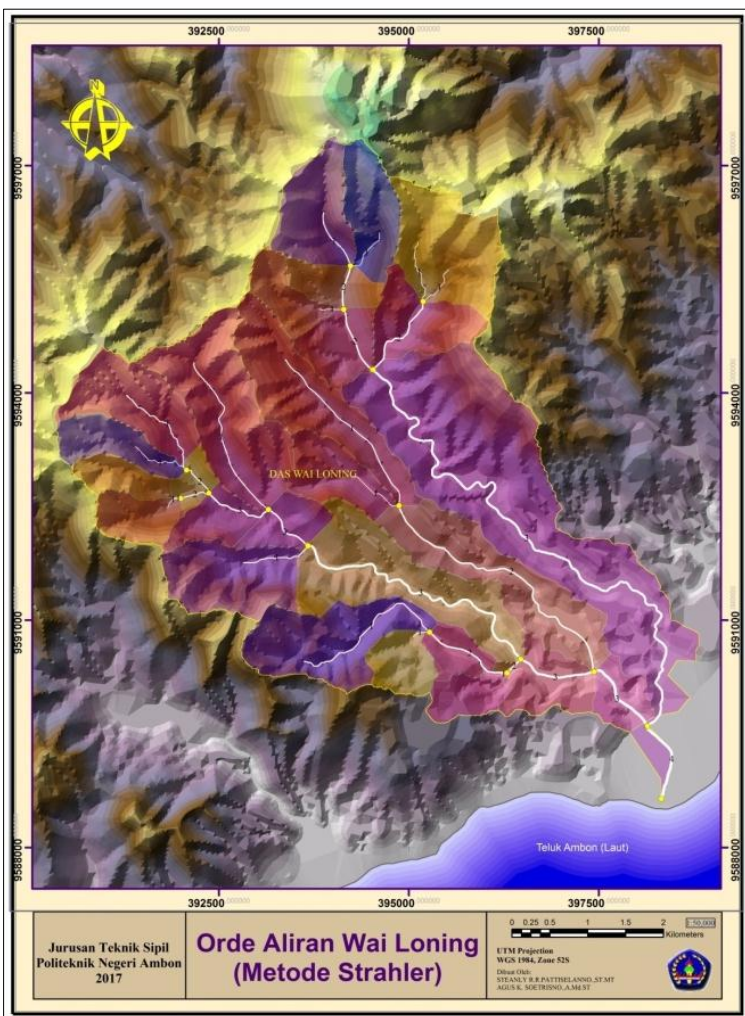

Sumber : Hasil Olahan, 2017

Gambar 5. Peta Orde Jaringan Sungai Wai Loning - Metode Strahle 


\section{JURNAL SIMETRIK VOL 7, NO. 2, DESEMBER 2017}

\subsection{Pembahasan}

Berdasarkan data atribut yang dihasilkan dari delineasi DAS Wai Loning, maka dapat diuraikan morfometri DAS Wai Loning sebagai berikut:

1) Luas DAS Wai Loning adalah $35.674 .050,00 \mathrm{~m}^{2}$ $\left(35,67 \mathrm{~km}^{2}\right)$ atau $3.567,405 \mathrm{Ha}$, dengan keliling $41.990,00 \mathrm{~m}(41,99 \mathrm{~km})$.

2) Panjang DAS yang merupakan jarak datar sepanjang sungai induk dari muara sampai ke hulu sungai yang diwakili oleh jaringan sungai dengan nomor $31,29,26,23,19$ dan 7 adalah sepanjang 10.673,6796 (10,67 km), dengan lebar DAS adalah perbandingan luas terhadap panjang DAS yaitu: $W=\frac{A}{L_{b}}=\frac{35,67 \mathrm{~km}^{2}}{10,67 \mathrm{~km}}=3,34 \mathrm{~km}$.

3) Kemiringan/gradien alur sungai utama Wai Loning adalah:

$$
S_{u}=\frac{\left(h_{85}-h_{10}\right)}{0,75 \cdot L_{b}}=\frac{(224-9,90) m}{0,75 \times 10.673,6796 m}=0,0267
$$

4) Orde pada jaringan sungai Wai Loning menurut metode Strahler adalah sampai dengan orde ke-4 dengan rincian sebagai berikut (Tabel 5.):

Tabel 5. Orde jaringan Sungai Wai Loning metode Strahler

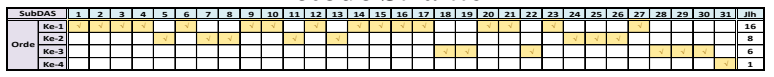

Sumber: Olahan Peneliti, 2017

Indeks percabangan (bifurcation ratio) sub DAS Wai Loning orde ke-1 adalah, $R_{b(1)}=\frac{N_{1}}{N_{1+1}}=\frac{16}{8}=2$, untuk orde ke-2 adalah, $R_{b(2)}=\frac{N_{2}}{N_{2+1}}=\frac{8}{6}=1,33$, untuk orde ke-3 adalah, $R_{b(3)}=\frac{N_{3}}{N_{3+1}}=\frac{6}{1}=6$. Sedangkan $W_{R b}$ untuk DAS Wai Loning adalah:

$W_{R_{b}}=\frac{\sum R_{b_{u} / u+1} \cdot\left(N_{u}+N_{u+1}\right)}{N_{u}}=\frac{2 \times(16+8)}{16}+\frac{1,33 \times(8+6)}{8}+\frac{6 \times(6+1)}{6}=12,33$

Dengan nilai $W_{R_{b}}$ (Weighted Mean Bifurcation Ratio) > 5, maka alur sungai pada DAS Wai Loning memiliki karakter sungai dengan kenaikan dan penurunan muka air banjir yang berlangsung dengan cepat.

5) Kerapatan alur sungai di DAS Wai Loning adalah, $D_{d}=\frac{L_{n}}{A}=\frac{42,50 \mathrm{~km}}{35,67 \mathrm{~km}^{2}}=1,19 \frac{\mathrm{km}}{\mathrm{km}^{2}} \quad$ dan termasuk ke dalam kategori indeks kerapatan aliran sungai dengan klasifikasi sedang $(0,25-$ $10 \mathrm{~km} / \mathrm{km}^{2}$ ), yaitu alur sungai melewati batuan dengan resistensi yang lebih lunak sehingga angkutan sedimen yang terangkut akan lebih besar (Soewarno, 1991).

6) Bentuk DAS Wai Loning dengan nisbah pendekatan kebulatan (circularity ratio) adalah, $R_{C}=\frac{4 \pi \cdot A}{P^{2}}=\frac{4 \pi \times 35,67 \mathrm{~km}^{2}}{(41,99 \mathrm{~km})^{2}}=0,25$, termasuk ke dalam kategori DAS berbentuk memanjang $\left(\mathrm{R}_{\mathrm{c}}<0,5\right)$ dengan karakter debit puncak yang datang dengan cepat, begitu juga penurunannya (Soewarno, 1991).

\section{PENUTUP}

5.1. Kesimpulan

Dari hasil penelitian ini, maka dapat disimpulkan:

1) Secara geografis, DAS Wai Loning terletak antara 3०40'6,51" - 3०43'19,50'LS dan $128^{\circ} 1$ '17,20” - $128^{\circ} 5^{\prime} 26,98^{\prime \prime}$ BT dengan luas $35.674 .050 \mathrm{~m}^{2}\left(35,67 \mathrm{~km}^{2}\right)$ atau $3.567,405 \mathrm{Ha}$, dan keliling $41.990 \mathrm{~m}(41,99 \mathrm{~km})$.

2) Morfometri DAS Wai Loning antara lain: panjang DAS 10.673,6796 (10,67 km); lebar Das 3,34 km; kemiringan/gradien alur sungai utama Wai Loning 0,0267; Orde jaringan sungai Wai Loning metode Strahler adalah sampai dengan orde ke- 4 , indeks percabangan $\left(R_{b}\right)$ orde ke-1 = 2 orde ke-2 = 1,33, dan orde ke-3 = 6 dengan Weighted Mean Bifurcation Ratio DAS Wai Loning $\left(W_{R_{b}}\right)=12,33$; kerapatan alur sungai $\left(D_{d}\right)=1,19 \frac{\mathrm{km}}{\mathrm{km}^{2}} ;$ nisbah pendekatan kebulatan bentuk DAS $\left(R_{c}\right)=0,25$. Berdasarkan hasil identifikasi data $W_{R_{b}}$ dan $R_{c}$, maka DAS Wai Loning termasuk karakter DAS dimana sungainya mengalami kenaikan dan penurunan muka air banjir yang berlangsung dengan cepat sertakarakter debit puncak yang datang dengan cepat, begitu juga penurunannya.

\subsection{Saran}

1) Dengan karakter sungai pada DAS sesuai analisa morfometri seperti pada kesimpulan di atas, maka DAS Wai Loning perlu dijaga tata kelola kawasan DAS yang mengarah pada konservasi lahan di bagian hulu agar tercegah dari kegiatan alihfungsi kawasan yang merusak tata kelola air yang berakibat bencana banjir/longsor yang merugikan masyarakat kawasan DAS serta merusak infrastruktur yang dibangun di aliran sungai Wai Loning.

2) Masyarakat dan stakeholder (instansi pemerintah /swasta) yang memiliki lahan, atau beraktifitas di area DAS Wai Loning perlu dirangkul dan disadarkan tentang orientasi konservasi tanah dan air di kawasan DAS, sehingga mereka bisa terlibat aktif untuk tidak menjadi bagian dari perusak kawasan DAS Wai Loning.

\section{DAFTAR PUSTAKA}

Asdak, C. 2004. Hidrologi dan Pengelolaan Daerah Aliran Sungai. Gadjah Mada University Press. Yogyakarta.

Badan Informasi Geospasial. 2008.

Nugroho, H. 2012. Aplikasi Hidrologi. Jogja Mediautama. Malang.

Peraturan Pemerintah Republik Indonesia Nomor 38 Tahun 2011 tentang Sungai. 
Prahasta, E. 2009. Sistem Informasi Geografis: Konsep-konsep dasar (Perspektif Geodesi \& Geomatika). Penerbit Informatika. Bandung.

Prahasta, E. 2004. Sistem Informasi Geografis: Tutorial Arc View. Penerbit Informatika. Bandung.

Seyhan, Ersin. 1977. Dasar-dasar Hidrologi. Editor, Soenardi Prawirohatmojo. Yogyakarta. UGM Press.

Sitanala, Arsyad. 2012. Konservasi Tanah dan Air, Edisi Kedua. IPB Press. Bogor.

Soewarno. 1991. Hidrologi: Pengukuran dan Pengolahan Data Aliran Sungai, (Hidrometri). Nova. Bandung.

Taufik H. Purwanto., 2013, Ektraksi Morfometri Daerah Aliran Sungai Dari Data Digital Surface Model (Studi Kasus Das Opak)[Online] Available at: http://geo.ugm.ac.id/wp-

content/uploads/doc/2013/05/EktraksiMorfometri-Daerah-Aliran-

Sungai.pdf[Accessed 24February 2016] 